\title{
POLLEN SPECTRUM OF HONEY OF "URUÇU” BEE (Melipona scutellaris LATREILLE, 1811)
}

\author{
CARVALHO, C. A. L. de, ${ }^{1}$ MORETI, A. C. de C. C., ${ }^{2}$ MARCHINI, L. C., ${ }^{3}$ ALVES, R. M. de \\ O. ${ }^{4}$ and OLIVEIRA, P. C. F. de ${ }^{3}$ \\ ${ }^{1}$ Escola de Agronomia, UFBA, C.P. 118, CEP 44380-000, Cruz das Almas, BA, Brazil \\ ${ }^{2}$ Instituto de Zootecnia, SAA-SP, C.P. 60, CEP 13460-000, Nova Odessa, SP, Brazil \\ ${ }^{3}$ ESALQ-USP, C.P. 9, CEP 13418-900, Piracicaba, SP, Brazil \\ ${ }^{4}$ Escola Agrotécnica Federal de Catu, CEP 48110-000, Catu, BA, Brazil \\ Correspondence to: Luís Carlos Marchini, Departamento de Entomologia, Fitopatologia e Zoologia Agrícola, \\ ESALQ-USP, C.P. 9, CEP 13418-900, Piracicaba, SP, Brazil \\ Received June 22, 1999 - Accepted April 25, 2000 - Distributed February 28, 2001
}

(With 1 figure)

\begin{abstract}
In spite of the importance of the "uruçu" bee as honey producer of excellent quality, as well, potential pollinator both in agricultural and natural ecosystems, mainly in North-eastern Brazil, just some information is found in literature about sources that such bees utilize to collect nectar and pollen. The identification of the plants visited by Melipona scutellaris was accomplished with base on the analysis of pollen types found in the honey samples collected every two months, from March 1997 to February 1998, in 15 colonies located in Catu, State of Bahia, Brazil (12²1'00"S, 38²2'40"W, 76 m of altitude). Qualitative and quantitative analysis of the pollen types were carried out determining the percentage and occurrence classes. Twenty-eight pollen types were found, being considered dominant pollen, the Eucalyptus spp. and Psidium sp. types and secondary pollen, Bauhinia sp., Caesalpinia sp. and Mimosa verrucata types. It was verified dominant pollen of Eucalyptus spp. in honeys produced in November/December 1997 and January/February 1998. The families Caesalpiniaceae (14\%), Mimosaceae (25\%) and Myrtaceae (56\%) were the most represented in the pollen spectrum.
\end{abstract}

Key words: pollen, honey, bee plants, Meliponinae.

\section{RESUMO}

\section{Espectro polínico do mel da abelha uruçu (Melipona scutellaris Latreille, 1811)}

Apesar da importância da abelha uruçu como produtora de mel de excelente qualidade, bem como polinizadora potencial de plantas em ecossistemas naturais e agrícolas, principalmente no nordeste brasileiro, poucas são as informações, encontradas na literatura, sobre as fontes que essas abelhas utilizam para coleta de néctar e pólen. A identificação das plantas visitadas por Melipona scutellaris foi realizada com base na análise dos tipos polínicos encontrados em amostras de mel coletadas bimestralmente de março de 1997 a fevereiro de 1998, em 15 colônias localizadas em Catu, Estado da Bahia, Brasil ( $12^{\circ} 21^{\prime} 00^{\prime \prime} \mathrm{S}, 38^{\circ} 22^{\prime} 40^{\prime \prime} \mathrm{W}, 76 \mathrm{~m}$ de altitude). Realizaram-se análises qualitativa e quantitativa dos tipos polínicos, determinando-se as porcentagens e classes de ocorrência. Foram encontrados 28 tipos polínicos, sendo considerados dominantes os de Eucalyptus spp. e Psidium sp. e acessórios os de Bauhinia sp., Caesalpinia sp. e Mimosa verrucata. Verificou-se a presença de pólen dominante de Eucalyptus spp. nos méis de novembro/dezembro de 1997 e janeiro/fevereiro de 1998. As famílias Caesalpiniaceae (14\%), Mimosaceae (25\%) e Myrtaceae (56\%) foram as mais representadas no espectro polínico contaminante do mel.

Palavras-chave: pólen, mel, plantas apícolas, Meliponinae. 


\section{INTRODUCTION}

The honey samples analysis supply information about bee flora in a determined region, becoming an important tool, both for apiculturist (Kerr et al., 1987), and researches. There are some controversies about the utilization of the pollen which is present in the honey as indication of botanical origin (Molan, 1998), but until the present date, this is the method most utilized for this purpose.

Among species of stingless bees the "uruçu" (Melipona scutellaris Latreille, 1811) is one of the most known in the Northeast of Brazil (Nogueira-Neto, 1970; Nogueira-Neto et al., 1986), being found in nests beehives and in rural and urban zones.

In spite of its importance as a potential pollinator in both agricultural and natural ecosystems and the peculiar quality of its honey, exists just some information about food sources that the "uruçú" utilize for nectar and pollen collection (Kerr et al., 1996).

The pollen spectrum analysis of honey indicates the plants visited by bees and permit the characterization of bee plants in a geographic region or time of the year. Can be used as auxiliary method in the indication of possible frauds in honeys found in the market (Durkee, 1971; Barth, 1989; Seijo et al., 1992).

The aim of this paper was to identify the plants visited by M. scutellaris, the "uruçu" bee by means of analysis of pollen types found in the honey.

\section{MATERIAL AND METHODS}

In the period from March 1997 to February 1998 every two months collections were accomplished in 15 colonies located in Catu, State of Bahia, Brazil (12²1'00"S, 38²2’40"W, 76 m of altitude). From each colony were taken off $10 \mathrm{ml}$ of honey which were deluded into $20 \mathrm{ml}$ of distilled water and centrifuged for 5 minutes at 2,500 rpm speed. After taking out the supernatant, the sediment which was found at the bottom of the test tube was included in non colored glycerin jelly and deposited in microscopic slides under tiny slide being sealed with paraffin (Barth, 1989).
The pollen types qualitative analysis was based on specialized literature (Barth, 1970a, b, c, 1989; Souza et al., 1993) and in the field information while the quantitative analysis was accomplished by means of consecutive counting of 200 grains, according to Ranta \& Lundberg (1981), determining the percentages and occurrence classes according to Louveaux et al. (1978) that classify the pollen types: dominant pollen (DP) (> 45\%), secondary pollen (SP) (16\% to $45 \%)$, important minor pollen (IMP)(3 to $15 \%)$ and minor pollen $(\mathrm{MP})(<3 \%)$.

\section{RESULTS AND DISCUSSION}

The visited flora, from March 1997 to February 1998, was represented by 28 pollen types, Bauhinia sp, Caesalpinia sp, Eucalyptus spp, Mimosa verrucata and Psidium sp. types were the most frequent (Table 1).

The Eucalyptus spp type appeared either as DP $(80.0 \%$ to $87.8 \%)$ or as SP $(19.18 \%$ to $33.6 \%)$ in practically all the samples, except that obtained in September/October 1997 (Tables 1 and 2). The pollen of the family Mimosaceae was found in all the samples, mainly as IMP, so this being the $M i$ mosa verrucata type was observed as SP in three samples: March/April (29.1\%), May/June (23.0\%) and July/August (20.8\%) (Table 1). The Psidium sp type was DP in one sample of September/October $(51.4 \%)$ (Table 1$)$.

The main pollen types found in honey samples of "uruçu" bee at the site studied are illustrated in the Fig. 1.

Comparing to literature data we certify that Eucalyptus spp. and Mimosa spp. types were also remarked by Barth (1989), Durán et al. (1996) and Moreti et al. (1998) in samples of Apis mellifera honey coming from Bahia. In spite of the Eucalyptus spp. type having been considered by Barth (1989), just as SP, it was observed that these species are found as DP in the samples of A. mellifera honey in different regions in the State of Bahia, principally due to the increase of reforested areas with this vegetable species in the latest years (Moreti et al., 1998).

Studies held in Amazon by Absy et al. (1980), identified 53 vegetable species whose pollen types were found in the nectar carried by forager bees of $M$. rufiventris and M. seminigra. 
TABLE 1

Percentage (\%) of pollen types in samples of Melipona scutellaris honey collected in Catu, State of Bahia, Brazil, from March 1997 to February 1998 (DP = dominant pollen > 45\%; SP = secondary pollen from 16\% to $45 \%$; IMP = important minor pollen from $3 \%$ to $15 \%$; and $M P=$ minor pollen $<3 \%$ ).

\begin{tabular}{|c|c|c|c|c|c|c|c|}
\hline \multirow{2}{*}{$\begin{array}{l}\text { Family } \\
\qquad \text { Genus/species }\end{array}$} & \multicolumn{5}{|c|}{1997} & \multirow{2}{*}{$\begin{array}{c}1998 \\
\text { Jan-Feb }\end{array}$} & \multirow{2}{*}{$\begin{array}{c}\% \text { Total } \\
\text { by family }\end{array}$} \\
\hline & Mar-Apr & May-Jun & Jul-Aug & Sept-Oct & Nov-Dec & & \\
\hline Myrtaceae & & & & & & & $56 \%$ \\
\hline Eucalyptus spp. & 33.57 (SP) & 19.18 (SP) & 28.86 (SP) & - & $87.80(\mathrm{DP})$ & $80.00(\mathrm{DP})$ & \\
\hline Myrtaceae type & - & - & - & 6.40 (IMP) & - & - & \\
\hline Psidium sp. & 3.78 (IMP) & 11.93 (IMP) & 10.85 (IMP) & 51.41 (DP) & 6.60 (IMP) & 10.20 (IMP) & \\
\hline \multicolumn{7}{|l|}{ Mimosaceae } & $25 \%$ \\
\hline Mimosa sp. & $0.47(\mathrm{MP})$ & - & - & - & $1.00(\mathrm{MP})$ & $1.20(\mathrm{MP})$ & \\
\hline $\begin{array}{l}\text { Mimosa } \\
\text { caesalpinifolia }\end{array}$ & - & - & 3.49 (IMP) & 9.72 (IMP) & - & - & \\
\hline Mimosa scabrella & - & 11.22 (IMP) & 8.46 (IMP) & 4.60 (IMP) & - & $1.40(\mathrm{MP})$ & \\
\hline Mimosa verrucata & $29.08(\mathrm{SP})$ & $23.01(\mathrm{SP})$ & $20.77(\mathrm{SP})$ & 5.37 (IMP) & - & - & \\
\hline Tibouchina sp. & 5.20 (IMP) & 4.69 (IMP) & 6.80 (IMP) & $2.30(\mathrm{MP})$ & $1.80(\mathrm{MP})$ & $1.00(\mathrm{MP})$ & \\
\hline Acacia type & - & - & - & $0.51(\mathrm{MP})$ & - & - & \\
\hline \multicolumn{7}{|l|}{ Caesalpiniaceae } & $14 \%$ \\
\hline Bauhinia sp. & $18.20(\mathrm{SP})$ & $1.70(\mathrm{MP})$ & 5.51 (IMP) & $0.26(\mathrm{MP})$ & - & - & \\
\hline Caesalpinia sp. 1 & 3.55 (IMP) & $27.13(\mathrm{SP})$ & $1.58(\mathrm{MP})$ & - & - & - & \\
\hline Caesalpinia sp. 2 & - & - & 3.31 (IMP) & 10.23 (IMP) & - & - & \\
\hline \multicolumn{7}{|l|}{ No identified (NI) } & $4 \%$ \\
\hline NI sp. 1 type & 5.20 (IMP) & - & - & - & - & - & \\
\hline NI sp. 2 type & $0.24(\mathrm{MP})$ & - & $0.37(\mathrm{MP})$ & 3.07 (IMP) & $2.00(\mathrm{MP})$ & $1.80(\mathrm{MP})$ & \\
\hline NI sp. 3 type & - & $0.14(\mathrm{MP})$ & $0.55(\mathrm{MP})$ & - & - & - & \\
\hline NI sp. 4 type & - & - & $2.94(\mathrm{MP})$ & - & - & - & \\
\hline NI sp. 5 type & - & - & $0.74(\mathrm{MP})$ & - & - & - & \\
\hline NI sp. 6 type & - & - & $1.29(\mathrm{MP})$ & - & - & - & \\
\hline NI sp. 7 type & - & - & $0.18(\mathrm{MP})$ & - & - & - & \\
\hline NI sp. 8 type & - & - & - & $2.30(\mathrm{MP})$ & - & - & \\
\hline NI sp. 9 type & - & - & - & 3.07 (IMP) & $0.40(\mathrm{MP})$ & $0.60(\mathrm{MP})$ & \\
\hline NI sp. 10 type & - & - & - & $0.36(\mathrm{MP})$ & - & - & \\
\hline NI sp. 11 type & - & - & - & $0.26(\mathrm{MP})$ & - & - & \\
\hline \multicolumn{7}{|l|}{ Arecaceae } & $0.72 \%$ \\
\hline Arecaceae type & - & 0.99 (MP) & - & - & - & 3.20 (IMP) & \\
\hline Astrocaryum sp. & - & - & - & - & - & $0.40(\mathrm{MP})$ & \\
\hline \multicolumn{7}{|l|}{ Asteraceae } & $0.25 \%$ \\
\hline Asteraceae type & $0.71(\mathrm{MP})$ & - & - & $0.51(\mathrm{MP})$ & $0.20(\mathrm{MP})$ & - & \\
\hline Sonchus sp. & - & - & - & - & $0.20(\mathrm{MP})$ & - & \\
\hline \multicolumn{7}{|l|}{ Moraceae } & $0.03 \%$ \\
\hline Cecropia sp. & - & - & - & - & - & 0.20 & \\
\hline
\end{tabular}



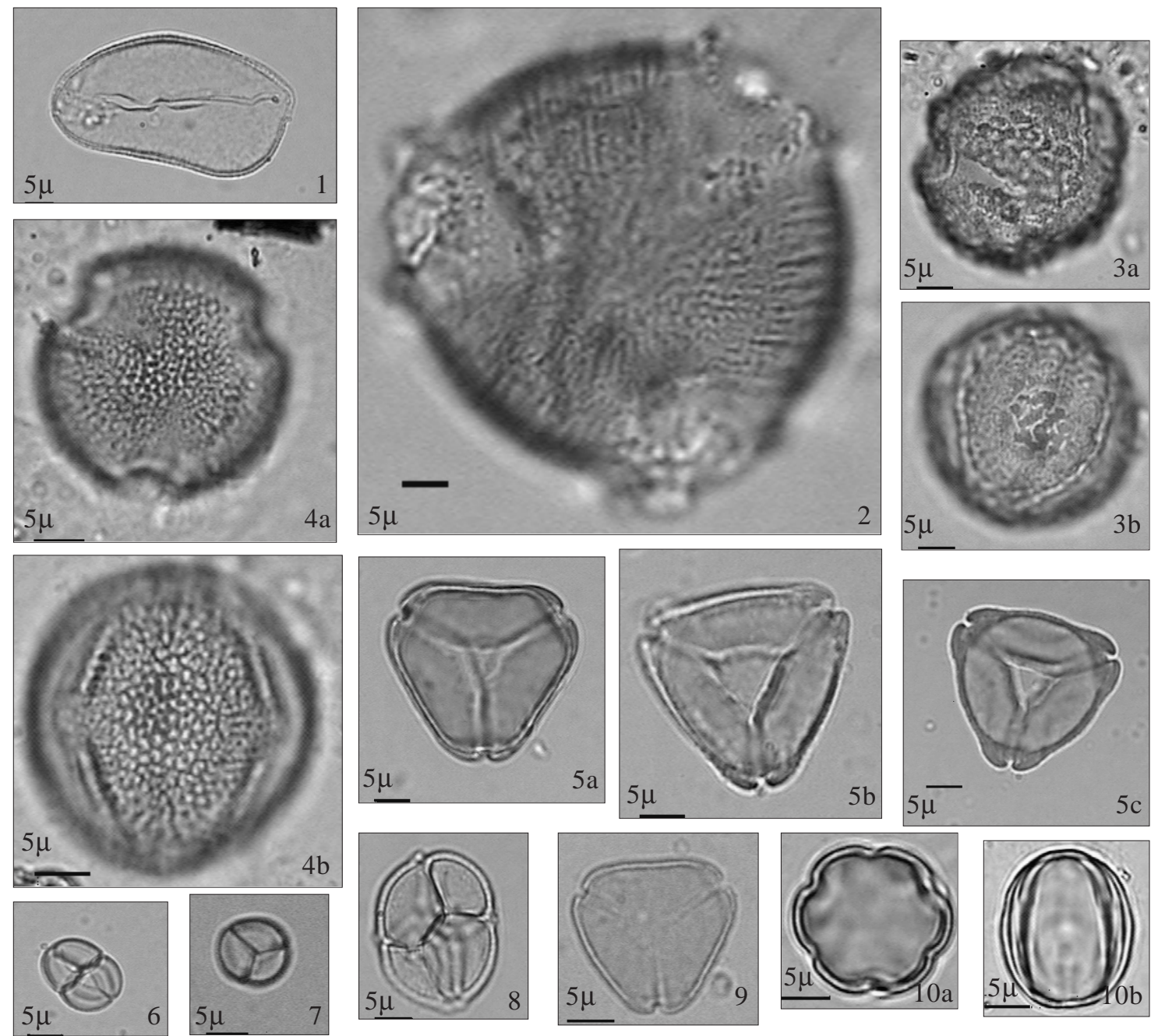

Fig. 1 - Main pollen types in samples of Melipona scutellaris honey collected in Catu, State of Bahia, Brazil, from March 1997 to February 1998. 1- Arecaceae type; 2 - Bauhinia sp. 3 - Caesalpinia sp. 1, a) polar view, b) Equatorial view; 4 Caesalpinia sp. 2, a) polar view, b) Equatorial view; 5a,b,c - Eucalyptus spp.; 6 - Mimosa caesalpinifolia; 7 - Mimosa scabrella; 8 - Mimosa verrucata; 9 - Myrcia type (Psidium sp.); 10 - Tibouchina sp. a) Polar view, b) Equatorial view.

In this work just 28 types were found in the honey produced by $M$. scutellaris. We believe that those differences are not only related to the bee species, but also to the diversity and characteristics of the local flora, edapho-climatic conditions, distance from the colonies to the food sources and vegetation degradation level, among other factors.

In the list presented by Kerr et al. (1987) containing 79 species of plants visited by M. compressipes fasciculata in the State of Maranhão, in Northeast of Brazil, for nectar and pollen collection, the authors considered as good nectar pro- ducers, 27 species among them Eucalyptus spp. e Bauhinia sp., which ones were also verified in the present survey.

Results obtained in this work get near those ones found by Vit \& d'Albore (1994) who studied the pollen spectrum in 48 honey samples of three species of Melipona in Venezuela, verifying that 28 samples contained dominant pollen, being 11 of Mimosa spp. and 3 of Myrtaceae. It was observed also similarity with the list of plants visited by Meliponinae and A. mellifera in neotropical region presented by Ramalho et al. (1990) in which 
were reported 8 species of Mimosa and 5 species of Eucalyptus.

The families Caesalpiniaceae, Mimosaceae and Myrtaceae were those that presented the greater number of species in pollen spectrum of the collected samples (Table 1). Those families were well represented in several studies with bee plants (Guibu et al. 1988; Ramalho et al., 1990), as species of Caesalpiniaceae that presents ample distribution and are part of several Meliponinae and A. mellifera diet supplying both pollen and nectar (Sommeijer et al., 1983; Ramalho et al., 1994).

\section{CONCLUSION}

The Eucalyptus spp. type was considered DP in "uruçu" bee honey produced in November/December 1997 and January/February 1998. The other samples presented a moisture of pollen types, without dominance of one, being main plants visited: Eucalyptus spp., Psidium sp., Mimosa verrucata, Bauhinia sp., Caesalpinia spp. and Mimosa scabrella.

\section{REFERENCES}

ABSY, M. L., BEZERRA, E. B. \& KERR, W. E., 1980, Plantas nectaríferas utilizadas por duas espécies de Melipona da Amazônia. Acta Amazonica, 10: 271281.

BARTH, O. M., 1970a, Análise microscópica de algumas amostras de mel. 1- pólen dominante. Anais da Academia Brasileira de Ciências, 42: 351-366.

BARTH, O. M., 1970b, Análise microscópica de algumas amostras de mel. 2- pólen acessório. Anais da Academia Brasileira de Ciências, 42: 571-590.

BARTH, O. M., 1970c, Análise microscópica de algumas amostras de mel. 3- pólen isolado. Anais da Academia Brasileira de Ciências, 42: 747-772.

BARTH, O. M., 1989, O pólen no mel brasileiro. Gráfica Luxor, Rio de Janeiro, 150p.

DURÁN, J. E. T., CORTOPASSI-LAURINO, M., ISSA, M. R. C., TOLEDO, V. de A. A. de, BASTOS, E. \& SOARES, A. E. E., 1996, Méis brasileiros: resultados de análises físico-químicas e palinológicas. In: Congresso Brasileiro de Apicultura, 11, Teresina. Resumos, p. 403-429.

DURKEE, L. H., 1971, A pollen profile from woden bog in North-Central Iowa. Ecology, 52: 837-844.

GUIBU, L. S., RAMALHO, M., KLEINERT-GIOVANNINI, A. \& IMPERATRIZ-FONSECA, V. L., 1988, Exploração dos recursos florais por colônias de Melipona quadrifasciata (Apidae, Meliponiane). Rev. Brasil. Biol., 48: 299305 .
KERR, W. E., ABSY, M. L. \& SOUZA, A. C. M., 1987, Espécies nectaríferas e poliníferas utilizadas pela abelha Melipona compressipes fasciculata (Meliponinae, Apidae), no Maranhão. Acta Amazonica, 16/17: 145-156.

KERR, W. E., CARVALHO, G. A. \& NASCIMENTO, V. A., 1996, Abelha uruçu - biologia, manejo e conservação. Fundação Acangaú, Belo Horizonte, 144p.

LOUVEAUX, J., MAURIZIO, A. \& VORWOHL, G., 1978, Methods of melissopalynology. Bee World, 59: 139-157.

MOLAN, P., 1998, The limitations of the methods of identifying the floral source of honey. Bee World, 79(2): 5968.

Moreti, A. C. de C. C., CARvalho, C. A. L. de, MARCHINI, L. C. \& OLIVEIRA, P. C. F. de., 1998, Espectro polínico de amostras de méis de Apis mellifera L. coletadas na Bahia. In: Congresso Brasileiro de Apicultura, 12, Salvador, Resumos, 189p.

NOGUEIRA-NETO, P., 1970, A criação de abelhas indígenas sem ferrão. 2ª ed. Chácaras e Quintais, São Paulo, $365 \mathrm{p}$.

NOGUEIRA-NETO, P., IMPERATRIZ-FONSECA, V. L., KLEINERT-GIOVANNINI, A., 1986, Biologia e manejo das abelhas sem ferrão. Tecnapis, São Paulo, 54p.

RAMALHO, M., KLEINERT-GIOVANNINI, A. \& IMPERATRIZ-FONSECA, V. L., 1990, Important bee plants for stingless bees (Melipona and Trigonini) and africanized honeybees (Apis mellifera) in neotropical habitats: a review. Apidologie, 21: 469-488.

RAMALHO, M., GIANNINI, T. C., MALAGODI-BRAGA, K. S. \& IMPERATRIZ-FONSECA, V. L., 1994, Pollen harvest by stingless bee foragers (Hymenoptera, Apidae, Meliponinae). Grana, 33: 239-44.

RANTA, E. \& LUNDBERG, H., 1981, Food niche analyses of bumble-bees: a comparison of three data collecting methods. Oikos, 36: 12-16.

SEIJO, M. C., AIRA, M. J., IGLESIAS, I. \& JATO, M. V., 1992, Palynological characterization of honey from La Coruña province (NW Spain). Journal of Apicultural Research, 31: 149-155.

SOMMEIJER, M. J., ROOY, G. A., PUNT, W. \& BRUIJN, L. L. M., 1983, A comparative study of foraging behavior and pollen resources of various stingless bees (Hym., Meliponinae) and honeybees (Hym., Apinae) in Trinidad, West-Indies. Apidologie, 14: 205-224.

SOUZA, V. C., CORTOPASSI-LAURINO, M., SIMÃOBIANCHINI, R. PIRANI, J. R., AZOUBEL, M. L., GUIBU, L. S. \& GIANNINI, T. C., 1993, Plantas apícolas de São Paulo e arredores. In: J. R. Pirani \& M. Cortopassi-Laurino (coord.), Flores e abelhas em São Paulo. Edusp, São Paulo, pp. 43-179.

VIT, P. \& D'ALBORE, G. R., 1994, Melissopalynology for stingless bees (Apidae: Meliponinae) from Venezuela. Journal of Apicultural Research, 33: 145-154. 